\title{
Figyelemfelhívás magyar polytrauma regiszter indítására Egy tömegbaleset bemutatása
}

\author{
DR. CSONKA ENDRE'1, DR. TUBOLY ESZTER², DR. JÁVOR PÉTER', DR. VARGA ENDRE
}

\section{ÖSSZEFOGLALÁS}

Az utóbbi évtizedekben a sürgősségi traumatológia területén elért fejlődés és paradigmaváltások országos és nemzetközi regiszterek, valamint nagy elemszámú kohortok elemzésein alapultak. Cikkünk összesen 20 személy sérülésével járó tömegbaleset bemutatásán és az érintettek kezelése során nyert adatok elemzésén keresztül hívja fel a figyelmet a hazai trauma regiszter indításának szükségességére. A bemutatni kívánt tömegbaleset sérültjei közül kiválogattuk a súlyos sérülést szenvedett (Injury Severity Score $\geq 16$ ), helyszínen nem reszuszcitált, 16 . életévet már betöltött személyeket. Ezen betegeknek a sérüléstől számított 6 . és 72 . órában levett rutin laborparaméterei kigyüjtésre kerültek. A paraméterek változásai, illetve egymással való kapcsolatuk Spearman-rangkorrelációk segítségével, SigmaStat 12.0 programban került elemzésre. 2017. október 3-án 8 súlyos sérült (átlagéletkor: 34,85+-2,97; medián Injury Severity Score: 31.5 [27.5-37]) érkezett egy időben a sürgősségi osztályunkra. Szignifikáns negatív kapcsolat igazolódott a 6 órás fehérvérsejtszám és a 72 órás kreatinin szint között ( $r s=-0,949 ; p=0,0167)$, valamint a 6 órás trombocitaszám és a 72 órás kreatinin szint között ( $r s=0,876 ; p=0,0833$ ). Hat és 72 órával a sérülés után mért rutin laborparamétereknek a két mintavétel között eltelt időintervallumban való változását vizsgálva a kreatinin, fehérvérsejt- és trombocitaszám mutattak szignifikáns változást. Súlyos sérülés után 6 és 72 órával mért kreatinin, fehérvérsejt- és trombocitaszámok kombinációban vizsgálva prediktív értékkel bírhatnak a kezelés kimenetelére. Új prognosztikus faktorok feltárásában egy esetleírás erősen korlátozott értékkel bír, véleményünk szerint eredményeink igazolásához és a hazai traumatológiai kutatás további fejlődéséhez egy magyar trauma regiszter elindítása lenne szükséges.

\section{Kulcsszavak: $\quad$ Polytrauma; Regiszterek; Sérülések; Szisztémás gyulladásos immunválasz szindróma; Többszervi elégtelenség; Tömegbaleset;}

\section{E. Csonka, E. Tuboly, P. Jávor, E. Varga: Need for a National Trauma Registry-Presentation of a mass casualty}

In the past decades, the development and paradigm shifts of trauma care were based on national and international registry and large cohort analyzes. The present study underlines the need for a Hungarian trauma registry through the presentation and analysis of a mass casualty with 20 injured people. Severely injured (Injury Severity Score $\geq 16$ ), adult ( $\geq 16$ years of age) patients who did not receive cardiopulmonal resuscitation on scene, were selected. 6 and 72 hour post-injury routine labor parameters were collected retrospectively. The changes and associations of the parameter were analyzed with Spearman rank correlation tests in SigmaStat 12 software. On the 3rd October 2017, 8 severely injured patients (mean age: 34,85+-2,97, median Injury Severity Score: 31.5 [27.5-37]) arrived to our Emergency Department at the same time. Our statistical analysis revealed a significant negative relationship between white blood cell count at 6 hours and blood creatinine level at 72 hours ( $r=-0.949 ; p=0.0167$ ) and between platelet count at 6 hours and creatinine at 72 hours ( $r s=0,876 ; p=0,0833$ ). The combination of these associations might have a predictive value for the outcome. Creatinine, white blood cell and platelet counts showed significant changes when their values at 6 and 72 hours were compared. The associations of creatinine levels, white blood cell and platelet counts measured at 6 and 72 hours post-injury might have a predictive 
value for the outcome in severe trauma. A case study has strong limitations in revealing new prognostic factors, therefore the establishment of a national trauma registry is required in order to validate our results and foster the development of Hungarian trauma research.

Keywords:

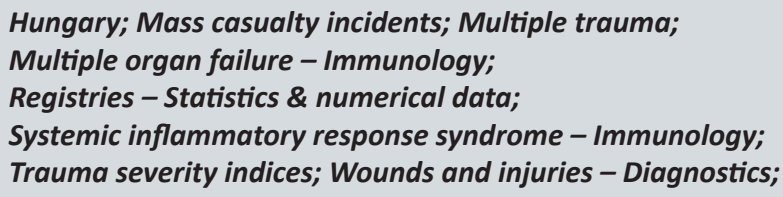

\section{BEVEZETÉS}

A súlyos sérültek (ISS $\geq 16$ ) vizsgálata és kezelése manapság is az egészségügyi ellátórendszerek kiemelten fontos feladata, hiszen zömében fiatalokat érint, és napjainkban is magas halálozással jár $(6,7)$. A súlyos trauma utáni első napot túlélők nagy számban érintettek posztoperatív szövődmények által és nagy kockázatúak a gyulladásos szervi diszfunkcióval járó kórállapotokra, szisztémás gyulladásos immunválasz szindrómára (SIRS), szepszisre és szervi elégtelenségekre nézve (2, $3,15)$. Ezen betegpopuláció terápiája rendkívül költséges és időigényes, átlagosan 2 hét intenzív osztályos (ITO) ellátással és elhúzódó rehabilitációs idővel jár (9). Habár a súlyos sérülések következményeinek társadalmi jelentősége vitathatatlan, az alkalmazott diagnosztikai és ellátási stratégiák még napjainkban is relatíve kevés tudományos evindenciával vannak alátámasztva. Az utóbbi évtizedekben, a sürgősségi traumatológia területén elért fejlődés és paradigmaváltások országos és nemzetközi regiszterek, valamint nagy elemszámú kohortok elemzésein alapultak (13, 14, 16). $A z$ egységes célból és módon, strukturáltan gyűjtött nagymennyiségú adat nyújtotta lehetőségeket felismerve a trauma regiszterek használata Nyugat-Európában egyre elterjedtebbé vált, és egy Egyesített Európai Trauma Regiszter koncepciója is megszületett (5). Tekintve, hogy régiónkban nem múködik trauma regiszter, rendkívül nagyszámú tudományos adat marad feldolgozatlanul. Egy polytrauma regiszter számos lehetőséget nyitna meg a hazai klinikusok számára, emellett a magyar traumatológiai ellátás magas színvonala azt is lehetővé tenné, hogy regiszterünk a jövőben egy európai szintű kollaboráció része lehessen.

Jelen cikkünk egy tömegbaleset bemutatásán és elemzésén keresztül hivatott felhívni a figyelmet hazai polytrauma regiszter szükségességére.

\section{ANYAG ÉS MÓDSZER}

\section{Etikai engedély}

A vizsgálat a Helsinki Egyezmény értelmében, a Szegedi Tudományegyetem Orvos Etikai Bizottságának engedélyével zajlott, az alábbi referenciaszámmal: 182/2019-SZTE.

\section{Esetkiválasztás, adatgyújtés}

Jelen cikkünk olyan tömegbalesetet mutat be, amely során több személy is súlyos sérüléseket szenvedett (ISS $\geq 16$ ), azonban nem igényelt kardiopulmonális reszuszcitációt a helyszínen. A mindössze könnyű sérüléseket szerzett, valamint a 16 . életévet be nem töltött sérültek kizárásra kerültek a vizsgálatból. Az SZTE Traumatológiai Klinikán kívül, egyéb intézményben első ellátásra került sérülteket szintén kizártuk elemzésünkből. A betegek demográfiai adatai, ISS-e, 6 és 72 órával a baleset elszenvedése után levett laborparaméterei (bázisdeficit/többlet, laktát, fehérvérsejtszám (WBC), trombocitaszám (PLT), kreatinin, bilirubin, AST, ALT, GGT), illetve mortalitásuk retrospektíven, Med-Solution rendszerből került kigyűjtésre, excel adattáblában.

\section{Statisztikai analízis}

A kinyert betegadatok statisztikai programban (Sigma Stat 12.0) kerültek elemzésre. A demográfiai adatokból deskriptív statisztika készült. A felvett laborparaméterek közötti lineáris kapcsolatok feltárására Spearman-korrelációt, a 6 és 72 órás laboreredmények összehasonlítására Wilcoxon-próbát használtunk. 


\section{EREDMÉNYEK}

\section{Esetbemutatás}

2017. október 3-án egy hétszemélyes mikrobusz a hatóságok elől nagy sebességgel menekülve letért az útról, felborult, majd többször átfordult. Az átalakított, utasülések nélküli hétszemélyes jármúben a sofőrön kívül 19 személy utazott, köztük 3 gyerek. Az éjszakai órákra való tekintettel légi mentés nem volt elérhető. A földi mentőegységek két utast a jármű alá szorulva találtak. Egy utas a helyszínen az életét vesztette, két személyen kritikus állapotuk miatt helyszíni újraélesztést kellett kezdeni, 9 súlyos, 8 utas pedig könnyebb sérüléseket szenvedett. A 9 súlyos sérültből 2 még nem töltötte be a 16. életévét, 1 személyt pedig elsőként nem az SZTE Traumatológiai Klinikára szállítottak a mentőegységek. Mindezek következtében 6 páciens került bevonásra analízisünkbe (1. ábra).

A helyszínen minden sérültnél perifériás vénabiztosítás, intravénás fájdalomcsillapítás, valamint krisztalloid infúzió bekötése történt, a nyaki gerinc és a sérült végtagok rögzítése mellett. Egy beteget intubálva, lélegeztetve szállítottak, a többi sérült arcmaszkon keresztül 100\% 02 szupplementációval került szállításra. Az átlagos szállítási idő az elhúzódó műszaki mentés miatt $111 \pm 28,61$ perc volt.

Az SZTE Traumatológiai Klinika betegei ATLS protokoll szerint kerültek ellátásra, klinikánk bázisa a magyarországi ATLS tanfolyamoknak, a legtöbb kollégánk és a társszakmák képviselői is nagy számban végezték el kurzusainkat. A sérültek triage beosztása döntötte el, melyik team látja el sérüléseit. Minden team egy traumatológusból (C, E doktor), egy aneszteziológusból ( $A, B, D$ doktor), egy traumás nővérből és egy aneszteziológus asszisztensből állt. A két kiskorú sérült stabilizálást és másodlagos állapotfelmérést követően a Gyermekklinika Gyereksebészeti Osztályára került. Két felnőtt személy az ITO-ra, majd mútőbe került, egy non-responder sérültet pedig azonnal mútőbe szállítottak, ahol azonban életét vesztette. Minden beavatkozás a damage controll surgery szellemében történt, a töréseket elsődlegesen fixateur externe-nel rögzítettük. Egy sérült intracranialis vérzését idegsebész látta el.

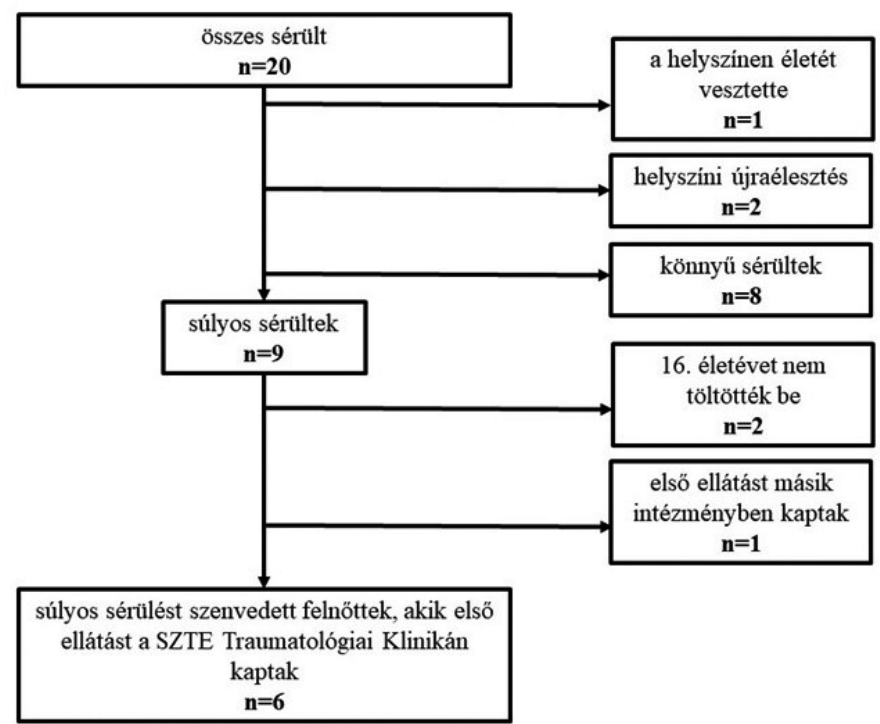

1. ábra Betegek beválogatása az analízisbe.

A bemutatni kivánt tömegbalesetben 20 személy sérült. Egy ember a helyszínen életét vesztette. Két személyen a mentöegységek a helyszínen újraélesztést kezdtek, 8-an pedig csak könnyebb sérüléseket (ISS <16) szenvedtek, így kizárásra kerültek az analízisböl. A fennmaradó 9 súlyos sérült (ISS \16) közül 2-en még nem töltötték be 16. életévüket, 1 személyt pedig a mentők egy másik vidéki kórházba szállitottak első ellátásra. Végül 6 személy adatai kerültek elemzésre. 
A sérültek demográfiája és laborparaméterei

2017. október 3-án 8 személy, 6 felnőtt és két kisgyermek érkezett egyszerre az SZTE Sürgősségi Betegellátó Osztályára többszörös törésekkel és tompa testüregi traumás sérülésekkel. A felnőttek átlagéletkora $34.85 \pm 2.97$ év, medián ISS-ja 31.5 [27.5-37] volt. A tömegbaleset következményeként az intézetünkben kezelt sérültek közül egyetlen személy hunyt el (l. táblázat).

\section{I. táblázat A sérültek demográfiai adatai és laborparaméterei}

Az analizishez kiválasztott felnött sérültek átlagéletkora 34.85£2.97 év, medián ISS-je 31.5 [27.5-37] volt. Egyetlen haláleset történt, 16.66\%-os mortalitási rátát eredményezve.

\begin{tabular}{|c|c|c|}
\hline Demográfia és mortalitás & & \\
\hline Életkor átlag \pm SD & \multicolumn{2}{|c|}{$34.85 \pm 2.97$} \\
\hline Férfi nem \% & \multicolumn{2}{|c|}{83.44} \\
\hline ISS & \multicolumn{2}{|c|}{$36.83 \pm 14.93$} \\
\hline ISS medián [IQR] & \multicolumn{2}{|c|}{$31.5[27.5-37]$} \\
\hline Mortalitás (\%) & \multicolumn{2}{|c|}{16.66} \\
\hline Laborparaméterek & 6 órával a sérülés után & 72 órával a sérülés után \\
\hline Bázisfelesleg/többlet (mmol/l) & $-2.13 \pm 2.90$ & $0.47 \pm 3.09$ \\
\hline Laktát (mmol/l) & $3.23 \pm 1.50$ & $1.27 \pm 0.67$ \\
\hline WBC (G/L) & $18.69 \pm 6.22$ & $7.56 \pm 0.91^{*}$ \\
\hline PLT (G/L) & $251.83 \pm 80.99$ & $126.00 \pm 19.15^{*}$ \\
\hline Kreatinin ( $\mu \mathrm{mol} / \mathrm{l})$ & $88.00 \pm 13.58$ & $63.5 \pm 5.97^{*}$ \\
\hline Bilirubin $(\mu \mathrm{mol} / \mathrm{l})$ & $10.34 \pm 1.32$ & $24.73 \pm 17.51$ \\
\hline AST (U/I) & $79.4 \pm 20.05$ & $70.33 \pm 26.57$ \\
\hline $\operatorname{ALT}(U / I)$ & $64.4 \pm 22.26$ & $51.33 \pm 34.36$ \\
\hline GGT (U/I) & $29.6 \pm 18.42$ & $19.67 \pm 14.22$ \\
\hline
\end{tabular}

${ }^{*} \mathrm{P}>0.05$ 


\section{Statisztikai vizsgálatok eredménye}

A 6 órás WBC és a 72 órás kreatinin szint között ( $r s=-0,949 ; p=0,0167$ ), valamint a 6 órás PLT és a 72 órás kreatinin szint között ( $r s=0,876$; $\mathrm{p}=0,0833$ ) szignifikáns negatív korreláció igazolódott, ezen változásoknak lehet prediktív ereje kombinációban vizsgálva (2. ábra).

A 6 és 72 órával a sérülés után mért rutin laborparamétereknek a két mintavétel között eltelt időintervallumban való változását vizsgálva a PLT, WBC és kreatinin szintek mutattak szignifikáns változást (2. ábra).
A

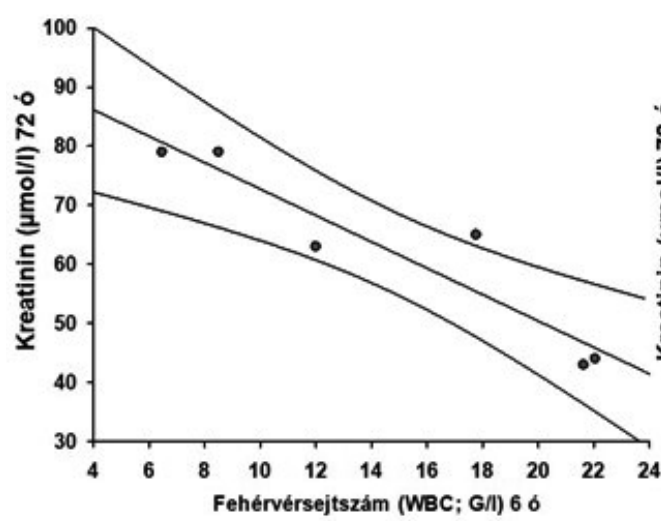

B

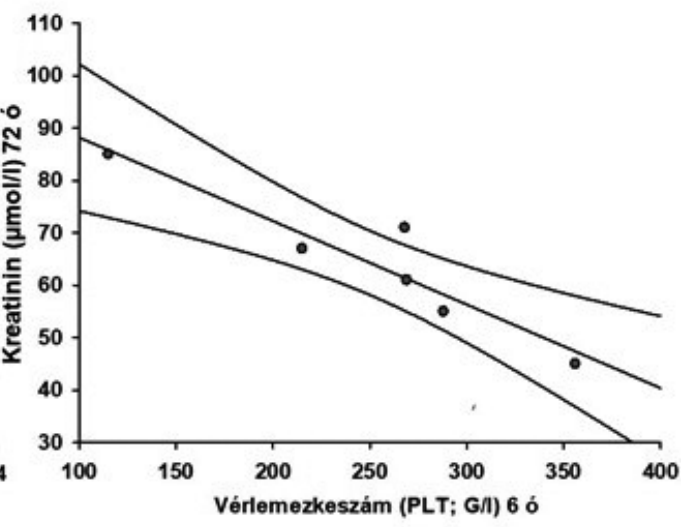

2. ábra Szignifikáns kapcsolatok a 6 és 72 órás laborparaméterek között.

A 6 órás WBC és a 72 órás kreatinin szint között ( $r s=-0,949 ; p=0,0167)(2 A)$, valamint a 6 órás PLT és a 72 órás kreatinin szint között ( $r s=0,876 ; p=0,0833)(2 B)$ szignifikáns negativ kapcsolat igazolódott.

\section{MEGBESZÉLÉS}

\section{Eredmények interpretálása}

Jelen cikkünk olyan tömegbalesetet mutat be, amelyben összesen 20 személy volt érintett. A súlyos sérültek kezelése során nyert adatok elemzésre kerültek. Vizsgálataink a sérülés után 6 és 72 órával levett rutin laborparaméterek változásainak dinamikáját, illetve egymással való kapcsolatát célozták meg a kezelés kimenetelére nézve potenciálisan prediktív értékkel bíró, új összefüggések kimutatása céljából.

A szakirodalomban jól dokumentált tény, hogy jelentős sérülések után a szöveti károsodás erős immunmodulátor hatású markerei szabadulnak fel, olyan hiperakut gyulladáskeltő citokinekkel mint a tumor nekrózis faktor- $\alpha$ (TNF- $\alpha$ ) és interleukin 1B, (IL-1B). A citokin felszabadulás Toll-like receptorok (TLR) aktivációját okozza 1-2 órával később (10). Ezt a folyamatot a legjobban tetten érni közvetlenül a baleset után lehetne, egy helyszíni vérvétellel. A korai, szubakut citokinek (IL-6, IL-8, és IL-12, IL-18), valamint kemokinek és leukocita migrációs faktorok felszabadulása polimorfonukleáris sejt túlaktiválódást és reaktív oxigén gyökök (ROS) képződését okozza, melyek súlyosan befolyásolják a sérülés, illetve a kezelés kimenetelét (9). A fenti reakciók csúcsa a sérüléstől számított 4 és 12 óra között van $(1,11)$, így 6 órával a trauma után történő mintavétel ezen korai fázis vizsgálatára megfelelőnek túnik. Széles körben elfogadott, hogy a korai nagymértékű pro-inflammatorikus és a későbbi anti-inflammatorikus folyamatok képesek egymást facilitálni, destruktív immunológiai disszonanciát fenntartva (2). Ez nagyon súlyos következményekhez, SIRS-hez, többszervi elégtelenséghez (MOF) vezethet az első 72 órában (4). Mintavételeinket azért időzítettük 6 és 72 órával a sérülés után, hogy a laborparaméterek változását a fent leírt fázisokban vizsgálhassuk.

Vizsgálatunkban a 6 órás WBC és a 72 órás kreatinin szint között, valamint a 6 órás PLT és 
a 72 órás kreatinin szint között szignifikáns negatív kapcsolat igazolódott, ezen változásoknak lehet prediktív ereje kombinációban vizsgálva. Szemléltettük, hogy egyetlen baleset elemzése hipotézisek felállítására ugyan alkalmas mennyiségú, azonban egyértelmú következtetések levonásához kevés, illetve korlátozott értékű tudományos információt szolgáltathat. Tudományos hipotézisek validálásához nagy mennyiségű, egységes célból és módon, strukturáltan gyưjtött adatokra van szükség, amelyre megoldást egy hazai trauma regiszter elindítása szolgálhatna. A trauma regiszterek tartalmazzák a sérültek demográfiai adatait, a sérülés körülményeit, prehospitális ellátást és transzportot, az első intézeti ellátás beavatkozásait, a sérülések anatómiai leírását, fiziológiai paramétereket, szövődményeket és a kimenetelt. Fontos és gyújtendő adat a megelőző betegségek szerepeltetése, amelyek a kortól és a sérülések súlyosságától függetlenül is befolyásolják a kimenetelt. A jól dokumentált regiszter tartalmazza a laborértékeket is, amelyek elővetíthetnek rizikó faktorokat és másodlagos triggereket nem kívánatos események bekövetkeztéhez, ugyanakkor alkalmasak tudományos rizikó felmérésre, algoritmus alapú prediktív információkat adhatnak a kimenetelre. Fontos, hogy jó leírást adjon a helyi populációról, nemzeti regiszterként illeszkedve a nagyobb, összehasonlító regiszterekhez, és lehetőséget adjon a hasonlóságok és különbözőségek megfigyeléséhez.

\section{Következtetés}

A jelenlegi esetleírás és tanulmány a jól dokumentált, klinikailag és tudományosan átlátható adatbázisok fontosságát hangsúlyozza. Súlyos sérültek (ISS $\geq 16$ ) esetében, a kezelés 6. és 72. órájában mért laborparaméterek kombinációinak vizsgálata, ezen belül is a WBC, PLT és kreatinin értékek egymással való összefüggései prediktív értékkel bírhatnak a kezelés kimenetelére nézve. Új prognosztikus faktorok feltárásában egy esetleírás erősen korlátozott értékkel bír, így eredményeink validálásához, és a hazai traumatológiai kutatás további fejlődéséhez egy magyar trauma regiszter elindítása lenne szükséges.

\section{IRODALOM}

1. Bogner V., Keil L., Kanz K. G., Kirchhoff C., Leidel B. A., Mutschler W., Biberthaler P.: Very early posttraumatic serum alterations are significantly associated to initial massive RBC substitution, injury severity, multiple organ failure and adverse clinical outcome in multiple injured patients. Eur. J. Med. Res. 2009. 14. (7): $284-291$. https://doi.org/10.1186/2047-783X-14-7-284

2. Bone R. C.: Immunologic dissonance: a continuing evolution in our understanding of the systemic inflammatory response syndrome (SIRS) and the multiple organ dysfunction syndrome (MODS). Ann. Intern. Med. 1996. 125. (8): 680-687. https://doi.org/10.7326/0003-4819-125-8-199610150-00009

3. Chen G. Y., Nuñez G.: Sterile inflammation: sensing and reacting to damage. Nat. Rev. Immunol. 2010. 10. (12): 826-837. https://doi.org/10.1038/nri2873

4. Dewar D., Moore F. A., Moore E. E., Balogh Zs.: Postinjury multiple organ failure. Injury. 2009. 40. (9): $912-918$. https://doi.org/10.1016/i.injury.2009.05.024

5. Edwards A., Di Bartolomeo S., Chieregato A., Coats T., Della Corte F., Giannoudis P., Gomes E., Groenborg H., Lefering R., Leppaniemi A., Lossius H. M., Ortenwal P., Roise O., Rusnak M., Sturms L., Smith M., Thomsen A. B., Willett K., Woodford M., Yates D., Lecky F.: A comparison of European Trauma Registries. The first report from the EuroTARN Group. Resuscitation. 2007. 75 (2): 286-297. https://doi.org/10.1016/i.injury.2006.06.066

6. Evans J. A., van Wessem K. J. P., McDougall D., Lee K.A., Lyons T., Balogh Zs. J.: Epidemiology of traumatic deaths: comprehensive population-based assessment. World J. Surg. 2010. 34 (1): 158-163. https://doi.org/10.1007/s00268-009-0266-1

7. Evans J. A., van Wessem K. J. P., McDougall D., Lee K. A., Lyons T., Balogh Zs. J.: Epidemiology of traumatic deaths: comprehensive population-based assessment. World J. Surg. 2010.34 (1): $158-163$. https://doi.org/10.1007/s00268-009-0266-1

8. Fröhlich M., Driessen A., Böhmer A., Nienaber U., Igressa A., Probst C., Bouillon B., Maegele M., Mutschler M.: Is the shock index based classification of hypovolemic shock applicable in multiple injured patients with severe traumatic brain injury? An analysis of the TraumaRegister DGU ${ }^{\circledR}$. Scand. J. Trauma Resusc. Emerg. Med. 2016. 24. (1): 148. https://doi.org/10.1186/s13049-016-0340-2

9. Hemmila M. R., Cain-Nielsen A. H., Wahl W. L., Vander Kolk W. E., Jakubus J. L., Mikhail J. N., Birkmeyer N. J.: Regional collaborative quality improvement for trauma reduces complications and costs. J Trauma Acute Care Surg. 2015. 78. (1): 78-85. https://doi.org/10.1097/TA.0000000000000494 
10. Hietbrink F., Koenderman L., Rijkers G., Leenenet L.: Trauma: the role of the innate immune system. World J. Emerg. Surg. 2006. 1: 15. https://doi.org/10.1186/1749-7922-1-15

11. Keel M., Trentz O.: Pathophysiology of polytrauma. Injury. $2005 . \quad 36 \quad$ (6): 691-709. https://doi.org/10.1016/j.injury.2004.12.037

12. Kernacki K. A., Goebel D. J., Poosch M. S., Hazlett L. D.: Early cytokine and chemokine gene expression during Pseudomonas aeruginosa corneal infection in mice. Infect. Immun. 1998. 66. (1): 376-379. https://doi.org/10.1128/IAl.66.1.376-379.1998

13. Mutschler M., Fau-Nienaber U., Brockamp T., Wafaisade A., Fabian T., Paffrath T., Bouillon B., Maegele M., TraumaRegister DGU: Renaissance of base deficit for the initial assessment of trauma patients: a base deficit-based classification for hypovolemic shock developed on data from 16,305 patients derived from the TraumaRegister DGU ${ }^{\circledR}$. Crit. Care. 2013. 17. (2): R42. https://doi.org/10.1186/cc12555

14. Mutschler M., Paffrath T., Wölfl C., Probst C., Nienaber U., Schipper I. B., Bouillon B., Maegele M.: The ATLS(®) classification of hypovolaemic shock: a well established teaching tool on the edge? Injury. 2014. 45. (Suppl. 3): S35-38. https://doi.org/10.1016/i.injury.2014.08.015

15. Oka Y., Murata A., Nishijima J., Yasuda T., Hiraoka N., Ohmachi Y., Kitagawa K., Yasuda T., Toda H., Tanaka N. et al.: Circulating interleukin 6 as a useful marker for predicting postoperative complications. Cytokine. 1992. 4. (4): $298-304$. https://doi.org/10.1016/1043-4666(92)90070-8

16. Roberts I., Shakur H., Coats T., Hunt B., Balogun E., Barnetson L., Cook L., Kawahara T., Perel P., Prieto-Merino D., Ramos M., Cairns J., Guerriero C.: The CRASH-2 trial: a randomised controlled trial and economic evaluation of the effects of tranexamic acid on death, vascular occlusive events and transfusion requirement in bleeding trauma patients. Health Technol. Assess. 2013. 17. (10): 1-79. https://doi.org/10.3310/hta17100

\section{Dr. Csonka Endre}

Szegedi Tudományegyetem, Traumatológiai Klinika

6725 Szeged, Semmelweis u. 6. 